\title{
An Economic Analysis on the Use of Hot Water Seed Treatment, Mulching and Pruning in the Control of Black Rot Disease in Cabbage with in Kisii County
}

\author{
Jackson Ombuna Gitange*, Johnson Nyangeri and Samson Maobe
}

School, of pure and applied sciences, Kisii University, 408-40200, Kisii-Kenya

*Corresponding author

\section{Keywords \\ Cabbage, \\ Profitability, Hot \\ water seed \\ treatment, Mulching and Pruning}

\section{Article Info}

Accepted:

07 November 2018

Available Online:

10 December 2018

\section{A B S T R A C T}

Cabbage farming in Kisii County is faced with a number of challenges, top among them being pests and disease damages. Black rot disease has been identified as one of the major reason responsible for the low yields in cabbage. As such, a number of Biotechnological approaches such as Mulching, hot water seed treatment, pruning, biocontrol agents, use of resistant varieties and chemicals have been employed to manage the disease. However, these approaches have been found to have many shortcomings such as being expensive and thus increasing the cost of production, causing environmental pollution, not easily available to the farmers and others have even failed to manage the disease effectively hence subjecting farmer to risks of losing their investment capital. Therefore, this research study was carried out with the main objective being to examine the economic analysis of using hot water seed treatment, mulching, pruning and plant debris management to control black rot disease in cabbage farms. 50 grams of Gloria Hybrid cabbage seeds were inoculated with $10^{4} \mathrm{CFU} / \mathrm{ml}$ (Colony Forming Units) suspensions of the field bacterial isolates. A portion of the inoculated seeds was then treated with hot water using the Miller et al., 2005 ISTA (International Seed Testing Association) standard procedures while the second portion was left untreated. All the seeds were then established in separate nursery beds in a greenhouse for a period of 3 weeks before being transplanted into the main field where the impact of hot water seed treatment, mulching, pruning and plant debris management on cabbage yield through disease management was evaluated. The marketable yield was arrived at by working out the average weight of the individual cabbage heads randomly sampled from on-station field experiments in the two seasons running from 2017- 2018. The data obtained was analyzed using the Statistical Analytic system (SAS) with Analysis of Variance (ANOVA) to establish whether there was any significant difference among yields from the various field treatments. The 2017-2018 local market price rates and KALRO (Kenya Agricultural and Livestock Research Organization) cost rates were used to compute the net benefits and value/cost ratios (VCR). The results obtained showed that integration of all the three methods had the highest \% yield increase (78.3\%) with the highest VCR value of 6.2 hence was recommended as the most profitable technology for managing black rot disease in cabbage farms. 


\section{Introduction}

Cabbage (Brassica oleracea var. capitata L.) belongs to the family of Brassicaceae, formerly known as Cruciferae family (Hall et al., 2002; Arthur, 2012; USDA, 2012). The crop has its origin in Europe and has been grown extensively for over 2,500 years as a vegetable food crop (Williams, 1980; Grubben and Denton, 2004). In the 19th century, cabbage was grown intensively in Russia and northern Europe. During the second half of the 19th century, immigrant farmers from northern Europe introduced cabbage into USA (Williams, 1980; Alana et al., 2008) from where it spread into the rest of world. Cultivation of Cabbage is a multi-billion dollar industry worldwide (USDA, 2008). Commercially, it ranks as one of the most popular and important vegetable crop of all the Brassica family in the world due to its adaptability to a wide range soil types, climatic conditions, ease of cultivation and storage as well as its high nutritional value (AsianFarming, 2005). It is universally cultivated in all seasons as a garden, track and general farm crop (Williams, 1980; Evita, 2015; Pringati, 2013).

In 2007, the production of cabbage crop in the USA was 1.4 Million metric tonnes (USDA, 2008). In Kenya, cabbage ranked first among all the vegetable crops with a production yield of 344,774 metric tonnes in 2007 (MOA, 2007). The FAO report of 2013 indicates that the total global surface area under cabbage production in 2011 was 2359000 hectares. The best world cabbage producers in 2011 were China and India at 31750000 metric tonnes and $7 \quad 949 \quad 000$ metric tonnes respectively (FAO, 2013). In Kenya, cabbage production has shown mixed trends for a few years ago, that is 510000 metric tonnes in 2009, 6000000 metric tonnes in 2010 and 523 000 metric tonnes in 2011. In 2012, Kenya was ranked as the $31^{\text {st }}$ best producer of cabbage worldwide with a production of 542,000 metric tonnes (MOA, 2012; HCDA, 2012).

The crop reflects its value as a vegetable crop that can be used as a source of food and income to most Kenyans (Kungu, 2005). White Cabbage is a highly nutritious source of food that contains high amount of vitamins and minerals; it is particularly abundant in Vitamins A, B6, C, K, folic acids, proteins and minerals such as calcium. It is also a high source of fibre, vegetable oil, component of fodder crop for livestock feed, and ingredient in condiments and spices. In addition to these uses, the crop has some medicinal values to human beings (Williams, 1980; Fahey et al., 2001; Alana et al., 2008). White cabbage has anti-carcinogenic properties and thus reduces the risk of some forms of cancer including colorectal cancers (Preedy et al., 2011). It is also a good meal for people with diabetes due to its low calorific content (Mike, 2009; Preedy et al., 2011). It can be eaten raw as salads, cooked, boiled or stuffed (Gitau, 2012).

Cabbage forms a major part of the Horticultural sector that earns Kenya Millions of shillings in foreign exchange (Kungu, 2005; Gitau, 2012). In addition, it provides employment to many Kenyans who grow it in small scale farms and sell it in local markets thus earning income. Production of cabbage as a small scale enterprise can financially empower the poor locals especially women and youths who are largely unemployed, have little capital, limited access to land and are working under labour constraints. The money obtained from the sale of cabbage contributes to food and nutritional security at the household level as well as enabling women and the youths to attain some degree of financial independence within the family budget (Lewis, 1997; MOA, 2000). Cabbage is produced in small scale, virtually in all parts 
of Kenya that fall between $800 \mathrm{~m}$ and $2900 \mathrm{~m}$ above sea level (Macharia et al., 2005; Polengs, 2011). The major cabbage production zones in Kenya are Kiambu, Nakuru, Nyandarua, Nyeri, Muranga, Narok, Kerinyaga and Laikipia. The small-scale cabbage producing areas include Kisii, Nyamira and Kericho among others (MOA, 1997; Macharia et al., 2005). The main local markets for the crop include the major cities such as Nairobi, Mombasa, Kisumu, Eldoret, Nakuru and nearly all County towns such Kisii.

For a long time, farmers in Kenya and more particularly, in Kisii County have not earned as optimally as they should from the production cabbage crop. This is because the farming of this crop is faced with many challenges that lower the average yields and income from this enterprise. Top among these challenges are large number of pests and disease, poor soil nutrition and excessive use of agrochemicals that affect the soil $\mathrm{pH}$ negatively. Black rot, caused by the bacterium Xanthomonas campestris $p v$. campestris (Pammel) Dowson, is considered as the most important and most destructive disease of cabbage and other crucifer crops, causing losses ranging between $30 \%$ and $70 \%$ in warm wet climates (Williams, 1980; Alvarez, 2000; Lo and Wang, 2001; Bila, 2008). Farmers in Kisii County have employed a number of methods to manage this disease. Some of the methods that have been used to control the disease include; use of tolerant varieties (Seebold et al., 2008), hot water treatment of seeds, use of cultural practices such as Mulching, crop rotation with noncruciferous plants, use of clean planting materials and disease-free transplants, pruning and removal of crop debris after harvest, control of cruciferous weeds, control of insects and use of biocontrol agents such as yeast (Celetti et al., 2002). Soil fumigation and chemical treatments of seeds have been used in an effort to control cabbage black rot.
Most of these biotechnological approaches have several shortcomings which need to be addressed before employing any technique in disease management. Some disease management techniques are too costly to the farmer, pollute the environment, difficult to implement while others are not easily accessible to farmers. Therefore, there is need to carefully examine all the available techniques and their shortcomings to avoid making wrong decisions that will subject farmers into risks of losing their capital investment. This paper attempts to carry out an economic analysis on the feasibility and profitability of using hot water treatment of seeds, mulching, pruning and management of plant debris to control black rot disease by farmers in Kisii County. A research carried out from 2017 to 2018 at the Kenya Agricultural and Livestock Research Organization (KALRO) center in Kisii County showed that all the three methods, separately as well as when integrated, had great impacts in the management of black disease which resulted into different levels of increase in the marketable yields obtained from the various field treatments.

This study was carried out with the knowledge that most Kenyan farmers have scarce capital and would only be willing to invest their money on technologies that are more feasible and profitable.

\section{Economic analysis}

Maurice (2012) argues that the performance of any farm is dependant of optimal utilization of the available resources. Excessive use of farm inputs may lead to excessive input costs while the output is not being maximized leading into a loss (Evita, 2015). The farmer's capital is scarcity and thus most farmers would want to invest only in technologies that are feasible and profitable to avoid the risks of losing their money. Most economists in Agriculture have identified the use of Benefit-Cost-Ratio, Gross 
margin Analysis (Adebayo, 2005), Value of Revenue/Cost Ratio (Evita, 2015), Partial budget analysis, Value/Cost Ratio (VCR) and the crop price to input ratio (Haisey and Mwangi, 1996; FURP, 1994; Maobe, 2016) as parameters of establishing the profitability of a new technology in farming. In this research work, the Partial Budget Analysis, Net benefits (Gross Margin Analysis), Value/Cost ratio (VCR), Minimum Returns Analysis and Riskiness were used as indicators to determine the feasibility and profitability of using hot water treatment of seeds, mulching, pruning and management of plant debris as well as their integration to manage black rot disease in Cabbage farms.

\section{Partial budget analysis}

According to Perrin et al., (1976) and as cited by Maobe (2016), Partial Budget Analysis refers to organizing the research data involving the costs of production and the benefits accruing from the various technologies under study in such a manner that can help a farmer to make particular decisions. The yields obtained from the various technologies under experimentation and their costs were organized in such a manner so as to enable the farmer work out the net benefits which would be used to identify the most feasible and profitable technology for managing black rot disease in cabbage farms. The total benefits were arrived at as the product of the marketable of cabbage per hectare and the best prevailing price at the local market at the time of experimentation. The net benefits were then arrived at as the difference between the total benefits and the total variable Costs (TVC). The Value/Cost ratios (VCR) were then worked out as the ratio between the net benefits and the total variable costs for each treatment. The VCR figures were then utilized to identify the most profitable treatment for recommendation to the farmers for adoption in their farms.
Gross margin analysis (Net Benefit Analysis)

The Gross Margin per hectare (GM) also known as the gross revenue or Net benefit was arrived at as the difference between the total income (total revenue) per hectare and the total variable costs per hectare and is expressed mathematically as shown below;

$\mathrm{GM}=\mathrm{TR}-\mathrm{TVC} \quad$ (Adebayo, 2005).

Whereby; GM - is the Gross margin from a production per hectare,

$\mathrm{TR}$ - is the Total Revenue/total income from a production per hectare,

TVC - is the Total Variable Costs from a production per hectare.

Total revenue was arrived at by multiplying the total output per hectare with the best prevailing market price. Adebayo (2005) reasons that Gross Margin is commonly used to determine the accruable profit to a farmer because it does not involve the value of fixed assets of the farmer which are minimal in the farm. The Gross margin is used to tests the effect of changes that do not alter the fixed costs of production such as land, farm tools and equipments. It is used to determine the potential profitability of a technology and its effect on the farmer's income. The advantage of using Gross margin/net benefit is that it is simple to use and can be used to analyze the profitability of technologies in small scale farms that have small fixed costs (Samm, 2009). The Gross Margin is in turn used to calculate the Marginal Rate of Return (MRR). According to Perrin et al., (1976), Shiluli et al., (2003) and as cited by Maobe (2016), the most profitable treatment/technology is one with the highest Marginal Rate of Return. They argue that treatments whose MRR is less than $100 \%$ have returns that cannot offset the total costs of production and at the same time generate reasonable profit margin to motivate farmers to adopt such technologies. 


\section{The Value/Cost ratio (VCR)}

Most Economists in the field of Agriculture have applied a VCR figure greater than 2 as the critical threshold to make a technology feasible and more profitable enough to convince the farmers to adopt it in their farms (Haisey and Mwangi, 1996; Maobe, 2016). Most Kenya farmers have scarce capital and would not want to invest it in non-profitable adventures. FURP (1994) while arguing that a VCR value of less than 2 reduces the margin of safety and thus subject farmers to risks of losing their investment capital, applies a VCR value of 2 to recommend the most profitable fertilizer application rate in maize production farms. Muriuki and Quireshi (2001) and as cited by Maobe (2016), are of the opinion that a VCR figure of less 2 but above 1.2 is only applicable in large-scale farming where there are few risks involved.

\section{Minimum returns analysis and riskiness}

Changes in crop yields and market prices can easily subject the farmer to risks of losing benefits and investment capital. Decline in yield can be as a result of change in weather conditions, management level and experimental error some of which are factors beyond the farmer's control. These factors can cause variation in yields from site-to-site and season-to-season to the extent that a technology with the highest net benefit in one season can results into losses beyond economic injury in the next season in the same experiment on the same site (Perrin et al., 1976; Maobe, 2016). According to Maobe (2016), risks arising from yield decline can averted by incorporating the risks aversion measures into a technology through Minimum Return Analysis earlier before the technology is implemented, while those risks due to variation in market prices can be taken care of by sensitivity analysis. Minimum Return Analysis works by evaluating the relative risk "disaster" among the technologies under study by computing the net returns to individual technologies and thereby choosing the alternative whose average returns of the worst outcomes is the highest among the technologies being considered. The mean of the first and the second worst net benefits from the various technologies under trial is then used to evaluate the relative risk of each technology (Perrin et al., 1976; Maobe, 2016). The technology/treatment with the lowest average minimum returns of the worst two outcomes was identified to be the most risky venture for the farmer.

\section{Materials and Methods}

The methodology in this research study has been discussed under the following subheadings; Land preparation, Inoculation of seeds, Field treatments, data collection and analysis and costs and prices.

\section{Land preparation}

Land for experimental plots was ploughed 3 times to a fine tilth and all weeds eliminated. The experimental plots measuring $4 \mathrm{~m}$ by $3 \mathrm{~m}$ were demarcated and labelled as shown in Table 1 below. Seedlings from the green house were then transplanted into the plots at a spacing of $60 \mathrm{~cm}$ by $60 \mathrm{~cm}$. Diammonium phosphate (DAP) fertilizer was used during transplanting at the rate $50 \mathrm{~kg} / \mathrm{ha}$. Weeds were controlled through hand weeding, though the number times hand weeding done differed from treatment to treatment. Top dressing was done in the field using Calcium Ammonium Nitrate (CAN) fertilizer at the rate of $50 \mathrm{~kg} / \mathrm{ha}$. The plants were also sprayed with Match 50 EC insecticide to control pests.

\section{Inoculation of seeds}

50 grams of relatively clean seeds of Gloria hybrid variety were obtained from the Kenya 
seed company. A $100 \mathrm{ml}$ suspension of the field bacterial isolates (at the concentration of $10^{4} \mathrm{CFU} / \mathrm{ml}$ ) was prepared in $0.85 \%$ saline solution containing $1 \%$ Tween-20 and used to inoculate the seeds.

\section{Field treatments}

The artificially inoculated seeds were then divided into five lots labeled as; $\mathrm{H}_{1}, \mathrm{M}_{1}, \mathrm{P}_{1}, \mathrm{I}_{1}$ and $\mathrm{I}_{0}$. The seeds labeled $\mathrm{H}_{1}$ were treated with hot water before nursery establishment. The $\mathrm{M}_{1}$ seeds were treated with hot water before nursery establishment and the seedlings from $\mathrm{M}_{1}$ seeds were later mulched in the field. $\mathrm{P}_{1}$ seeds were treated with hot water before nursery establishment and the seedlings from $\mathrm{P}_{1}$ seeds were later pruned as the plants were growing in the field. Those seeds labeled $\mathrm{I}_{1}$ received hot water treatment before nursery establishment. Both mulching and pruning was then done to $I_{1}$ seedlings as they were growing in the field. Only the plant parts showing disease symptoms were pruned and the diseased parts carefully disposed from the farm. Hot water seed treatment was done using the Miller et al., 2005 ISTA (International Seed Testing Association) standard procedures. There was no hot water treatment, no mulching and no pruning was done to $\mathrm{I}_{0}$ seeds to serve as a control experiment. All the seeds were then established in separate nursery beds in a green house for a period of 3 weeks before being transplanted the main fields.

In this experiment, a complete randomized block design was used to evaluate the feasibility and profitability of using hot water treatment of seeds, mulching, pruning and management of plant debris, separately and when integrated, to control black rot disease in cabbage farms. The treatments applied were replicated four times. This experiment was repeated twice in two different seasons, with the first trial covering long rain season in the months of April to August 2017 while the second trial covered the warms months of September to December 2017 with short rains.

\section{Data collection and analysis}

The yields from the field treatments were obtained by weighing the cabbage heads randomly sampled from each treatment in both season 1 and 2 . The mean weight of cabbage heads from both seasons was then worked out and used to determine the estimated marketable yield per hectare. The data obtained were computed by Statistical analysis system (SAS) using Analysis of Variance (ANOVA). The mean scores were also compared using mean separation procedures by Least Significance Difference (LSD) and the Tukey's multiple range test and all tests of significance were conducted at $\mathrm{P} \leq 0.05$ to establish whether there was any significant difference between yields from the various treatments. The results obtained were then used to work out the total benefit (gross income), the net benefit (Gross Margin Analysis) and the Value/Cost ratio (VCR) as indicators of feasibility and profitability of a farming technology to a farmer.

\section{Costs and prices}

In carrying out economic analysis, the folowing costs per hectare (Table 2) were considered against the various treatments and the value of yields from the various treatments (Table 3) were worked out using the local market price rates (that is, 2017-2018 price rates at Daraja Mbili market in Kisii town). The price rate used in this study was the minimum one for that period. This was so as to offset other unforeseen costs such as costs of transporting the product to the market that differ from one location to another within Kisii County. The costs shown below were also used to work out the value/cost ratios (VCR) as shown in Table 3, which would later 
be used to identify the most profitable treatment. The 2017-2018 price rates at Daraja Mbili market in Kisii town provided an average of Ksh. $10 \mathrm{~kg}^{-1}$ of cabbage heads, taken as the minimum of the available price. Cabbage heads were harvested and sold by way of their weights.

Table 2 above provides the various variable costs per treatment and the total variable costs at the 2017-2018 KALRO rates, Kisii branch, whereby $\mathrm{S} / \mathrm{No}$ refers to serial number for the item while $\mathrm{H}_{1}, \mathrm{M}_{1}, \mathrm{I}_{1}$ and $\mathrm{P}_{1}$ represents hot water seed treatment, mulching, integration, and pruning and plant debris management respectively.

The Kisii branch KALRO rates of 2017-2018 provided a Ksh. 600 per man-power per day with a 8 persons man-power per acre in land preparation and weeding, and another 15 persons man-power per acre being required for planting. Planting took more man-power and time than land preparation because it required employment certain skills such as measuring distance. Land was tilled 3 times before planting and the crop was weeded 3 times in fields with no mulching before harvesting. Fields with mulching required only one weeding as mulches supressed weed growth. Land hire rate was Ksh. 6000 per acre per year, $50 \mathrm{~kg} /$ acre DAP fertiliser sold at Ksh. 2950 while $50 \mathrm{~kg} /$ acre CAN fertiliser sold at Ksh. 1950 at the local shops in Kisii town. Mulch was locally available at a cost of Ksh. 100 per bag which included the transport cost and that 100 bags of mulch were required per acre.

\section{Results and Discussion}

In determining the relationship between a treatment costs, disease control and yields so as to identify the most profitable technology, 7 observations were made, which were the mean weight per cabbage head from the various field treatments in the two seasons, the mean marketable yield per hectare, the percentage yields increase per treatment, the total benefits from each treatment, total variable costs for each treatment, the net benefit for each treatment and the value/cost ratio for each treatment as demonstrated in Table 3. The details of the treatments shown in Table 3 are as follows:

$\mathrm{I}_{1}$ Hot water seed treatment + Mulching + Pruning.

$\mathrm{M}_{1}$ Hot water seed treatment + Mulching.

$\mathrm{P}_{1}$ Hot water seed treatment + Pruning.

$\mathrm{H}_{1}$ Hot water seed treatment only.

$\mathrm{I}_{0}$ Control (no Hot water seed treatment, no Mulching, no Pruning).

The average weight of a cabbage head was determined using the mean weight of the randomly sampled cabbage heads from each experimental plot of $4 \mathrm{~m}$ by $3 \mathrm{~m}$. The average weight of the cabbage heads was then used to compute the average yield from each experimental plot which was in turn used to determine the average yield per acre. Finally, the estimated marketable yield per hectare for each treatment was arrived at using the average yield per acre, assuming one hectare is equivalent to 2.471 acres.

Table 3 shows that there was significant difference between yields from fields with different treatments. Cabbage heads from fields with integration had significantly high weight scores $(3.25 \mathrm{~kg})$ as compared to heads from other field treatments. Heads of cabbage from hot water treatment of seeds had the lowest weight score $(2.875 \mathrm{~kg}$ ) as compared to heads from other treatments except the control $(1.823 \mathrm{~kg})$. A similar trend was observed in terms of marketable yields whereby integration had significantly $(\mathrm{p}<0.05)$ high marketable yields (94.791 tons/ha) as compared to all other treatments. Once again, hot water treatment of seeds had significantly 
lower marketable yields (67.144 tons/ha) except for the control (53.163 tons/ha). Integration had the highest percentage yield increase $(78.3 \%)$ as compared to all other treatments while hot water treatment of seeds had the lowest percentage yield increase (26.3 $\%)$. Integration had the highest value/cost ratio (6.2) while hot water treatment had the lowest value/cost ratio (4.3).

From figure 1, it is evident that integration had the highest marketable yields as compared to all the other treatments while the control experiment (that is, where there was no hot water treatment of seeds, no mulching was done and no pruning was carried) had the lowest marketable yields. This result therefore demonstrates that each treatment had a significant impact on the yields that could lead to higher income for the farmer.

\section{Minimum returns analysis and riskiness}

This was done a measure of cautioning the farmer against any risk of losing yields due to changes in weather conditions, change in management level and experimental error.

Table 4: Minimum Returns Analysis for using Hot water seed treatment, Mulching, Pruning and Integration in the management of Black rot disease of Cabbage in Kisii County

Table 4 above indicates that the Minimum Returns Analysis of the worst two treatments produces lower net benefits $(547,879)$ from hot water treatment alone as compared to the mean of the worst two treatments $(582,214)$. This therefore, demonstrates that farmers risk losing some benefits if they stop their cabbage production at the level of hot water treatment alone. It clearly indicates that the use of hot water treatment alone may have not effectively managed the disease and hence the lower yields that resulted to low net benefit. This therefore, calls for the need for other additional measures such as mulching, pruning and plant debris management in the control of black rot disease for optimal yields.

The Results obtained from this study showed that there was significant $(p<0.05)$ difference between yields from fields with different treatments. Cabbage heads from fields with integration had significantly high weight scores $(3.25 \mathrm{~kg})$ as compared to heads from other field treatments. Heads from hot water seed treatment had the lowest weight score $(2.302 \mathrm{~kg})$ as compared to all the other treatments except for the control which had $1.823 \mathrm{~kg}$ (Table 3). A similar trend was observed in terms of marketable yields of cabbage. Integration had significantly high marketable yields (94.791 tons/ha) as compared to all other treatments. Hot water treatment of seeds had significantly the lowest marketable yields (67.144 tons/ha) except for the control (53.163 tons/ha) as shown in Table 3. There was also significant difference between marketable yields from where mulching (83.854 tons/ha) and pruning (75.651 tons/ha) were done. As can be evidenced from table 4.19, integration had the highest percentage yield increase $(78.3 \%)$ with the highest VCR value at 6.2 as compared to all the other treatments while hot water treatment of seeds had the lowest yield increase $(26.3 \%)$ with the lowest VCR value at 4.3. It can also be observed that both mulching and pruning had higher percentage increase in marketable yields separately, that is, $57.71 \%$ and $42.3 \%$ with corresponding VCR values of 5.6 and 4.4 respectively when compared to hot water treatment of seeds alone. These results therefore demonstrate that each field treatment had a significant impact on disease control that resulted into significant increase in the marketable yields. The higher increase in the marketable yield would lead to a higher net profit with the highest VCR value from fields with integration as compared to all the other treatments and as such a good farm 
practice for controlling black rot disease of cabbage.

These research findings marry very well with those of Perrin et al., (1976), FURP (1994), Haisey and Mwangi (1996), Maobe (2016), Muriuki and Qureshi., (2001) and Shiluli et al., (2003) who identified partial budget analysis, Gross Marginal Analysis, value/cost ratio (VCR), the crop price to input price ratio, Minimum Returns Analysis and Riskiness as the main measures used to determine the feasibility and profitability of a new technology before it is recommended to the farmers for adoption in their farms. In Agricultural economics, the VCR has been described to be the most practical indicator that is easy to use when evaluating various technologies to determine the most profitable ones. The VCR ratio explains that for a new technology to be profitable to the farmers, it must raise the farmer's income by at least twice for smallholder farmers (Perrin et al., 1976; FURP, 1994).

Table.1 Randomized block design for the treatments in 4 replicas

\begin{tabular}{l|c|c|c|c|c|}
\hline Replica & & & Treatments & & \\
\hline Replica 1 & $\mathrm{I}_{1}$ & $\mathrm{H}_{1}$ & $\mathrm{P}_{1}$ & $\mathrm{I}_{0}$ & $\mathrm{M}_{1}$ \\
\hline Replica 2 & $\mathrm{P}_{1}$ & $\mathrm{M}_{1}$ & $\mathrm{I}_{1}$ & $\mathrm{H}_{1}$ & $\mathrm{I}_{0}$ \\
\hline Replica 3 & $\mathrm{I}_{0}$ & $\mathrm{P}_{1}$ & $\mathrm{M}_{1}$ & $\mathrm{I}_{1}$ & $\mathrm{H}_{1}$ \\
\hline Replica 4 & $\mathrm{M}_{1}$ & $\mathrm{I}_{0}$ & $\mathrm{H}_{1}$ & $\mathrm{P}_{1}$ & $\mathrm{I}_{1}$
\end{tabular}

This was done twice in 2 different seasons. In this case;

$\mathrm{H}_{1}$ - for hot water treatment of seeds,

$\mathrm{M}_{1}$ - for Mulching of plants in the field,

$\mathrm{P}_{1}$ - for Pruning of plants and management of plant debris in the field,

$I_{1}$ - Integrating hot water seed treatment with mulching and pruning of plants in the field,

$\mathrm{I}_{0}$ - Control (where no hot water seed treatment, no mulching and no pruning was done)

Table.2 Estimated costs/ha for each treatment at 2017-2018 KALRO rates, Kisii branch

\begin{tabular}{|l|l|l|l|l|l|l|}
\hline S/No & Item & Control $\left(\mathbf{I}_{\mathbf{0}}\right)$ & $\mathbf{H}_{\mathbf{1}}$ & $\mathbf{P}_{\mathbf{1}}$ & $\mathbf{M}_{\mathbf{1}}$ & $\mathbf{I}_{\mathbf{1}}$ \\
\hline $\mathbf{1}$ & $\begin{array}{l}\text { Hot water treatment of } \\
\text { seeds }\end{array}$ & - & 1,500 & 1,500 & 1,500 & 1,500 \\
\hline $\mathbf{2}$ & Mulching & - & - & - & 24,710 & 24,710 \\
\hline $\mathbf{3}$ & Pruning & - & - & 13,500 & - & 4,450 \\
\hline $\mathbf{4}$ & Weeding & 35,590 & 35,590 & 35,590 & 11,860 & 11,860 \\
\hline $\mathbf{5}$ & Land rent & 14,800 & 14,800 & 14,800 & 14,800 & 14,800 \\
\hline $\mathbf{6}$ & Land preparation & 35,590 & 35,590 & 35,590 & 35,590 & 35,590 \\
\hline $\mathbf{7}$ & Planting & 22,239 & 22,239 & 22,239 & 22,239 & 22,239 \\
\hline $\mathbf{8}$ & Fertiliser (DAP) & 7,289 & 7,289 & 7,289 & 7,289 & 7,289 \\
\hline $\mathbf{9}$ & Top dressing (CAN) & 4,818 & 4,818 & 4,818 & 4,818 & 4,818 \\
\hline $\mathbf{1 0}$ & Pesticides & 4,695 & 4,695 & 4,695 & 4,695 & 4,695 \\
\hline & Total variable costs $(\mathbf{K s h})$. & $\mathbf{1 2 5 , 0 2 1}$ & $\mathbf{1 2 6 , 5 2 1}$ & $\mathbf{1 3 9 , 6 9 1}$ & $\mathbf{1 2 7 , 5 0 1}$ & $\mathbf{1 3 1 , 9 6 1}$ \\
\hline
\end{tabular}


Table.3 Net benefits and value/cost ratio of cabbage yield response to different treatments

\begin{tabular}{|c|c|c|c|c|c|c|c|}
\hline $\begin{array}{l}\text { Treatmen } \\
\mathrm{t}\end{array}$ & $\begin{array}{l}\text { Cabbage } \\
\text { mean weight } \\
\text { (kg/head) }\end{array}$ & $\begin{array}{l}\text { Marketabl } \\
\text { e yeild } \\
\text { mean } \\
\text { (tons/ha) }\end{array}$ & $\begin{array}{l}\text { Per } \\
\text { cent } \\
\text { yield } \\
\text { increase }\end{array}$ & $\begin{array}{l}\text { Total } \\
\text { benefit } \\
\text { (Ksh) }\end{array}$ & $\begin{array}{l}\text { TVC } \\
\text { (Ksh) }\end{array}$ & $\begin{array}{l}\text { Net } \\
\text { benefit } \\
\text { (Ksh) }\end{array}$ & VCR \\
\hline $\mathbf{I}_{1}$ & $3.250 \mathrm{a}$ & $94.791 \mathrm{a}$ & 78.30 & 947,910 & 131,961 & 815,949 & 6.2 \\
\hline $\mathbf{M}_{1}$ & $2.875 \mathrm{~b}$ & $83.854 \mathrm{~b}$ & 57.71 & 838,540 & 127,501 & 711,039 & 5.6 \\
\hline$\overline{\mathbf{P}_{1}}$ & $2.594 \mathrm{c}$ & $75.651 \mathrm{c}$ & 42.30 & 756,510 & 139,961 & 616,549 & 4.4 \\
\hline$\overline{\mathrm{H}_{1}}$ & $2.302 \mathrm{~d}$ & $67.144 \mathrm{~d}$ & 26.30 & 674,400 & 126,521 & 547,879 & 4.3 \\
\hline$\overline{\mathbf{I}_{0}}$ & $1.823 \mathrm{e}$ & $53.163 \mathrm{e}$ & - & 531,630 & & & \\
\hline$\overline{\text { S.E }}$ & 0.038 & 1.112 & & & & & \\
\hline $\mathrm{CV}$ & 5.94 & 5.94 & & & & & \\
\hline P value & $<0.0001$ & $<0.0001$ & & & & & \\
\hline
\end{tabular}

Means figures in the column with different letters are significantly different $(\mathrm{p}<0.05)$. Price of cabbage $=$ Ksh. 10 $\mathrm{kg}^{-1}$ of cabbage head; 2017-2018 price rates at Daraja Mbili market in Kisii town, being taken as the most minimum prevailing prices at the time of experimentation.

Table.4 Minimum Returns Analysis for using Hot water seed treatment, Mulching, Pruning and Integration in the management of Black rot disease of Cabbage in Kisii County

\begin{tabular}{|l|l|l|}
\hline The two worst treatments & Treatment detail & Net benefits (Ksh.) \\
\hline The most worst treatment & Hot water treatment of seeds & 547,879 \\
\hline Second worst treatment & Pruning & 616,549 \\
\hline $\begin{array}{l}\text { Mean of the worst two } \\
\text { treatments }\end{array}$ & 582,214 \\
\hline
\end{tabular}

*Price of cabbage $=\mathrm{Ksh} .10 \mathrm{~kg}^{-1}$ of cabbage heads; 2017-2018 price rates at Daraja Mbili market in Kisii town being taken as the most minimum prices.

The net revenue/benefit was worked out as the difference between the total benefit and the total variable costs. The net revenue/benefit was used to calculate the value/cost ratios for each treatment which was later used to identify the most profitable treatment/technology (Perrin et al., 1976) that farmers would be easily convinced to invest their money on. The value/cost ratio was described as the value of yield increase due to the technology used per cost of the technology/treatment. In this study, the value/cost ratio was arrived at by comparing the net benefit of each treatment to its total variable costs as demonstrated by the formula below; 
$\mathrm{VCR}=\frac{\mathrm{NB}}{\mathrm{TVC}}$

2016)

Whereby; VCR is the value/cost ratio, NB is the net benefit for a treatment and TVC is the total variable costs for a treatment. Haisey and Mwangi, 1996 recommended a VCR greater than 2 as being the critical threshold for a technology to be profitable and thus convincing farmers to adopt it in their farms with ease. In this study, all the treatments had VCR values greater than 2 implying that all of them are economically viable and it would be prudent for the farmers adopt them. However, integration had the highest VCR value (6.2) which is significantly different from all the other treatments. Hot water treatment of seeds had the lowest VCR value (4.2). Table 3 also demonstrates that there is significant difference between the VCR value of integration (6.2) and that of Mulching (5.6) which corresponds well to the higher percentages in disease control and yields increase by integration as observed in Table 3. Table also illustrates that there is no much difference between the VCR values of hot water treatment of seeds and pruning in cabbage which again marries well with their effects in disease control and yield increase. The similarity between the VCR values of hot water treatment of seeds and pruning can be associated with the fact that pruning in cabbage farms is very much limited as excessive pruning will affect formation of cabbage heads negatively. The higher VCR values from Mulching and integration can linked to the Agricultural benefits of mulching such as soil conservation, conservation of soil moisture, suppressing of weeds which may compete with the main crop for nutrients and moisture, providing conducive environment for soil microbes all of which have the benefits of higher crop yields.

In conclusion, the research findings from this study showed there was significant difference $(p<0.05)$ between yields from fields with different treatments. The results also demonstrates clearly, that the all the treatments under study, that is, the use of hot water seed treatment, mulching, pruning and plant debris management separately and while integrated, had positive impact in the management of black rot disease in cabbage fields. This impact caused different percentage increase in the marketable yields, net benefits and Value/cost Ratios (VCR) for the various treatments under study as illustrated below:

1. Integration, at $78.30 \%$ caused the highest percentage yield increase and thus making the marketable yields for integration to increase from 53.163 tons/ha (for the control) to 94.791 tons/ha. This increase in yields resulted into the highest net benefit and Value/Cost ratio (VCR) of 6.2 for integration as compared to all the other treatments. The VCR value of 6.2 was far higher than VCR value of 2 which is the critical threshold recommended by most economists and as such, it is profitable for farmers to employ this technology in managing black rot disease in cabbage farms.

2. Mulching, with $57.71 \%$ yield increase, had the second highest impact on black rot disease management after integration. This caused the marketable yield to increase from 53.163 tons/ha (for the control) to 83.854 tons/ha. This yield increase gave the second highest net benefit with a VCR of 5.6 which was also higher than 2 and hence the technology is also profitable to adopt.

3. Pruning of infected parts of plants and management of plant debris made the marketable yields for this treatment to increase by $42.30 \%$, up from 53.163 tons/ha (for the control) to 75.65 tons/ha. Once again, this increase resulted into a relative higher net benefit with a higher VCR value of 4.4 which implies that the technology is also worthy 
using in the management of black rot disease.

4. Hot water seed treatment on its own had a positive impact on the management of black rot disease in cabbage fields which resulted into a $26.30 \%$ increase in the marketable yield, up from 53.163 tons/ha (for the control) to 67.144 tons/ha. The VCR value of hot water treatment was 4.3 , which was equally higher than the minimum recommended value of 2 implying that it is also a good disease management practice to employ.

However, the Minimum Returns Analysis done on the treatments showed that the net benefits from hot water treatment was less than the mean net benefit of the worst 2 treatments in this study. These results therefore, demonstrate that profit from cabbage farming may not be optimal if farmers stop their production at hot water treatment level.

\section{Recommendations}

From the study findings, integration had $78.30 \%$ yield increase and a VCR value of 6.2 which were the highest as compared to all the treatments under this study. On the basis of these research findings, integration was found to be the most profitable among all the treatments under this research study and is therefore recommended as the best technology for managing black rot disease in cabbage farms within Kisii County.

\section{References}

Adebayo, E.F. (2005). Application of Goal Programming to Resources Allocation Behavior of Dairy Producers in Adamawa State, Nigeria. Journal of Sustainable Development in Agriculture and Environment. 1 (1):60-69.

Alana, R., Viliam, Z. (2008). Vegetable Crops Production Guide for Nova Scotia. Agra point.

Alvarez, A. M. (2000). Black rot of crucifers. In: Slusarenko, A. J; Fraser, R. S. S; van, L. L. C (Eds.) Mechanisms of Resistance to Plant Diseases. Dordrecht, The Netherlands: Kluwer Academic Publishers. Pg 21-52.

Arthur, G. C. (2012). Colewort and Cole crops. University of California.

AsiaFarming. (2015). Cabbage cultivation: Cabbage farming information guide.

Bila, J. (2008). Status of Bacterial Black rot of Brassicas in Southern Region of Mozambique: Survey, Detection and Identification of the Causal Agent Xanthomonas campestris $p v$. campestris. M.Sc. thesis, University of Copenhagen, Denmark. pg102.

Celetti, M., Kristen C. (2002). Black Rot of Crucifer Crops. Ministry of Agriculture, Food and Rural Affairs. Ontario State.

Evita, S. H. (2015). Cabbage farm analysis. International Journal of Advances in Agricultural and Environmental Enng(IJAAEE) Vol. 2, Issue 2.

Fahey, J. W., Zalemann, A. T., Talalay, P. (2001). The chemical diversity and distribution of glucosinolates and isothiocyanates among plants. Phytochemistry, 56, pg 5-51.

FAO Statistics Database. (2013). Food and Agriculture Organization of the United Nations Report.

FURP (1994). Fertilizer Use Recommendation Project (FURP). Fertilizer Use Recommendations, Volumes 1 to 24. Kenya Agricultural Research Institute (KARI), National Agricultural Research Laboratories, Nairobi.

Gitau, M. (2012). Growing cabbages; Brassica oleracea in Kenya for wealth and employment creation.

Grubben, G.JH. and Denton OA. 2004. Plant resource of Tropical Africa and vegetables. PROTA foundation, 
Wageningen, Netherlands / Backlmys Publishers, Leiden,Netherlands / CTA Wageningen, Netherlands.

Heisey, P. W. and Mwangi, W. 1996. Fertilizer use and maize production in sub-saharan Africa. CIMMYT Economics working paper 96-01, Mexico, D. F. CIMMYT.

Hall, J. C., Sytsma, K. J., Iltis, H. H. (2002). Phylogeny of Capparaceae and Brassicaceae based on chloroplast sequence data. American Journal of Botany 89 (11): 1826-42.

HCDA. (2012). Domestic Marketing and Market infrastructure in Kenya. Government Press. Nairobi, Kenya. Pg15.

Kungu, N. W. (2005). Cabbage is a vegetable that heals: Agriculture Information Research Centre. Nairobi, Kenya.

Lewis, I. (1997). Network vegetable production Africa: its contribution to conservation and use of traditional vegetables, in Traditional African Vegetables. Proceedings of the IPGRI International Workshop on Genetic Resources of Traditional Vegetables in Africa. Pp. $159-160$.

Lo, C. T., Wang, K. M. (2001). Inoculum sources of Black Rot of Wasabi, caused by Phoma wasabiae. Plant Pathol Bull. 10: 88- 92 .

Macharia, I., Lohr, B., De Groote, H. (2005). Assessing the potential impact of Biological control of Plutella xylostella (diamondback moth) in cabbage production in Kenya. Journal of Crop protection 24(11): 981-989.

Maobe, S. N. (2016). Economic Analysis of Legume Biomass Nitrogen Application in Maize Production under Highland Conditions. African Journal of Agriculture and Utilization of Natural Resources for Sustainable Development, Volume 2 (1): 16-44.

Maurice, D.C. (2012). Optimal Farm Plan and
Resource Allocation in Food Crop Production in Adamawa State, Nigeria. Ph.D Thesis, Department of Agricultural Economics and Extension, Modibbo Adama Unversity of Technology, Yola. Pp. 11-19.

Mike, A. (2009). Natural Health News \& Self- Reliance.

Miller, S. A., Lewis, I. M. L. (2005). Hot water treatment of vegetable seeds to eradicate bacterial plant pathogens in organic production systems. Plant Pathology Extension Fact sheet HYG3086-05. The Ohio State University.

Ministry of Agriculture. (2012). County statistics Annual Authority Report. Government Press. Nairobi, Kenya. Pg 7.

Ministry of Agriculture. (2007). Republic of Kenya-Ministry of Agriculture Annual Report. Nairobi, Kenya.

Ministry of Agriculture and JICA. (2000). Local and export vegetables growing manual: Agriculture Information Resource Centre. Nairobi, Kenya.

Ministry of Agriculture. (1997). Regulation 1591/87 Annex 1 as amended by Regulation 888/97. Nairobi, Kenya.

Muriuki, A. W. and Qureshi, J. N. 2001. Fertilizer use manual. Kenya Agricultural Research Institute (KARI), Nairobi. 149 p.

Perrin, R. K., Winkelmann, D. L., Moscardi, E.R and Anderson, J. R. 1976. From agronomic data to farmer recommendations: An economics Training manual. International and maize improvement centre (CIMMYT), Mexico. 51p.

Preedy, R. V., Vatson, R. R., Patel, B. V. (2011). Nuts and Seeds in health and disease prevention. Academic press Publications of Elsevier, 32 Jamestown Road, London NW1 7BY, UK.

Pringati Singa. (2013). Analisis Usaha Kubis/Kol. Panduan Budidaya 
Tanaman.

Polengs. (2011). Budidaya Tanaman Sayur Kubis (Kol.). Budidaya New: Referensi Usaha Perianan, Peternakan, dan Pertanian.

Samm, B.M. (2009). Gross Margin Analysis and Linear Programming: Tools in understanding how Farmers in the Guinea Savannah Region of Nigeria rejected the most Profitable type of Sorghum recommended by Scientists. Proceedings; Pre-conference of the Western Agricultural Economics Association, 2009 meeting. June 24, pp. $1-20$.

Seebold, K., Bachi, P., Beale J. 2008. Black rot of crucifers. UK Cooperative Extension Service. University of Kentucky- College of Agriculture.

Shiluli, M. C., Macharia, C. N. and Kamau, A. W. 2003. Economic analysis of maize yield response to nitrogen and phosphorus in the sub-humid zones of western Kenya. African Crop Science Journal, Volume No. 3, pp. 181-187.

United States Department of Agriculture. (2012). Classification for species Brassica Oleracea L. Plants database.

Williams, P. H. (1980). Black rot: a continuing threat to world crucifers. Plant Disease 64 (8): 736-742.

\section{How to cite this article:}

Jackson Ombuna Gitange, Johnson Nyangeri and Samson Maobe. 2018. An Economic Analysis on the Use of Hot Water Seed Treatment, Mulching and Pruning in the Control of Black Rot Disease in Cabbage within Kisii County. Int.J.Curr.Microbiol.App.Sci. 7(12): 413426. doi: https://doi.org/10.20546/ijcmas.2018.712.052 